\title{
The Impact of Perceived Value \& Implementation of Good Governance to Satisfaction (The Study to Lectures at Public University)
}

\author{
Rivaldi Arissaputra ${ }^{1)}$, Sarah Sentika ${ }^{2)}$ \\ 1) Faculty of Economy and Humanity, 'Aisyiyah Bandung University \\ 2) Faculty of Economy and Humanity, 'Aisyiyah Bandung University \\ *Coresponding Author \\ Email : rivaldi.arissaputra@unisa-bandung.ac.id
}

\begin{abstract}
This research is a study form of perceived value and good governance in the satisfaction of lecturers in state universities. The purpose of this research is to analyze the effect of perceived value and good governance on satisfaction perceived by lecturers who teach in state universities in Bandung where the focus of this case study is the lecturers who teach at Padjadjaran University, the Bandung Institute of technology and the Indonesian University of Education. The survey technique used in data collection is a questionnaire with measurements using a Likert scale. Data collection technique used is purposive sampling with a total of 238 respondents. The analytical method used in this study is carried out using the Structural Equation Modeling (SEM) method with the help of Lisrel 8.24 software and to test the validity and reliability of the construct carried out with SPSS. The results showed that the variables perceived value and good governance affect the satisfaction of the lecturer where good governance has a greater influence than perceived value on lecturer satisfaction.
\end{abstract}

Keywords: perceived value, good governance, satisfaction, state universities, lecturers

\section{INTRODUCTION}

The 21st century is known as a century of knowledge which is the main foundation for various aspects of life. In the 21st century all aspects of life are moving towards globalization. Globalization is a process of gathering global networks that unite communities that were previously divided in various parts of the world into mutual dependencies in the world (Ritcher, 2010). The impact of globalization affecting education at the tertiary level is becoming increasingly important, including Indonesia (Public Lecture of Ahmad Dahlan University Yogyakarta by the Minister of Research, Technology and Higher Education Mohamad Nasir, March 22, 2018. The government that is represented by the Minister of Research, Technology and Higher Education, Mohamad Nasir has taken the main step in facing the globalization of education by giving direct directions that universities must apply the principles of good governance (transparency, fairness, accountability, and responsibility) in the management of their institutions.

In college education, lecturers play an important role. Currently, national universities are still lack of around 12,000 lecturers. In the field of education, lecturers as internal customers are individuals in other departments in the organization that are served by internal suppliers (Susana, 2012: 36) are the main assets owned by universities. Given that Indonesia is currently lack of lecturers, the role of the government is needed to meet the needs that will make the lecturers feel satisfied. Satisfaction that is felt can support lecturer teaching performance which has an impact on the quality of education at the tertiary level in Indonesia. The role of the government examined in this study is the application of good governance in the management of universities. Meanwhile, the need for lecturers who must be fulfilled can be 
assessed by the perceived value felt while working in college. Therefore, in this study the author will measure the satisfaction of lecturers in state universities based on intrinsic factors (perceived value) and perceived extrinsic factors (good governance). Based on the explanation above, the formulation of the research problem is how is the influence of perceived value variables on satisfaction of state university lecturers; and how is the variable effect of good governance on the satisfaction of public university lecturers. The purpose of the research is to identify the result of the research on the effect of perceived value variables on satisfaction of state university lecturers; and identify the results of the study of the influence of variable good governance on the satisfaction of public university lecturers.

The study of perceived value definition has been done long ago. Perceived value is experience formed by the consumer when buying a product or service that is a combination of: qualitative and quantitative, objective, and subjective factors (Schechter, 1984 in Zeithaml, 1988; cited in Snoj et al., 2004: 158). Perceived value is a comparison of consumer perception between what they receive and what they are given based on the utility of a product (Zeithaml, 1988: 14). In another study said that perceived values can be described as values formed by consumer evaluation of suppliers and trade-offs between benefits and sacrifices (Flint et al., 2002: 171; cited in Snoj et al., 2004: 158). In their daily consumption of goods / services perceived value can be felt by customers when the perceived benefit is greater than their perceived cost (Day, 1999), meaning perceived value is created from consumer perception to evaluate their product after service (Gale, 1994). Based on the above study, it can be concluded that the similarities and differences of all definitions above are divided into three concepts. The first concept, according to Zeithamal (1988), Day (1999), Flint (2002) perceived value is a value perceived by customer based on benefits and costs from consuming the product / services. The second concept, according to Schechter (1984 in Zeithaml, 1988 (cited in Snoj et al., 2004)) consider that perceived value experience is formed by the consumer when buying a product or service that is a combination of: qualitative and quantitative, objective and subjective factors. Another opinion from Gale (1994) as third concept said that the perceived value is created from consumer perception to evaluate the value of a product or service. Based on all concept above, the author develops the definition of perceived value is a value experience that is felt by consumers which is a combination of various factors related to the benefits they obtained and the cost they spend after consuming a product or services.

According to (Day, 1999) "perceived customer value = customer 'perceived benefit customer's perceived cost". Kotler (2003) listed about dimension total benefits (functional value, service value, personal value, image value) and total cost (monetary cost, time cost, energy cost and psychological cost) perceived by customer. In his research Jayakody, Samarasinghe and Kuruppu (2016) identified the effect of customer perceived value on customer satisfaction \& loyalty from case companies paying for TV services. The results of this study prove that customer satisfaction can be increased by perceived value (functional, emotional, social value, and epistemic) when meeting or exceeding customer service expectations. As for another research conducted by Xin, Changzeng and Bing (2016) regarding the influence of perceived value relationships (functional value, service value, emotional value, social and safety value) are felt on loyalty through customer satisfaction. The results of this study prove that the functional value, security value and perceived service affect customer satisfaction and customer loyalty. Sweenay \& Soutar (2001) said, 4 dimensions for perceived value: Emotional value, social value, Quality / Performance value and Price / Value of money. Emotional value is a utility that comes from the affective / positive emotion that results from consuming the product. Social value is a utility that is derived from the product's ability to improve the customer's social self-concept. Quality / performance value is the utility derived from the perception of quality and expected performance for the product and price / value of 
money is a utility obtained from the product due to the reduction of short-term costs and longterm costs (Sweeney and Soutar in Tjiptono, 2005: 298). After reviewing the theories above, measurement of perceived value can be done by replicating the perceived value dimension that is according to Sweeney and Soutar (2001) it is considered suitable to be applied in this study, namely emotional value, social value, quality / performance value, price / value of money. The values above come from customer interactions related to information, products, interaction employees and systems, environment (purchase \& consumption), and ownership (Smith \& Colgate, 2007).

Research on the implementation of good governance has been carried out in various countries and makes the definition of good governance varies. Good governance is a public level decision making procedure for the purpose of equitable and sustainable development based on transparent and accountable management of human, natural, economic, and financial management (Peterson, John, Shackleton, Michael, 2006). Good governance itself can be described as all forms of public policy and principles of governance that have been established and approved by all stakeholders Bovaird and Löffler (2003). While Santiso (2001) said that good governance can be defined as managing 3 public affairs: transparent, accountable, and fair in a two-way interaction between government and social organizations, community relations, decision-making, and accountability. Good governance reflects a government that responds to public demand that asks the government to be good quality, clean and responsible (Widodo, 2001). It is not different from the experts above, Franz (2013) defined that good governance is an activity in taking important decisions transparently and involves public opinion to form a good governance principle (Franz, 2013). Based on the above study it can be concluded that the similarities and differences of all definitions above are divided into three concepts. The first concept, according to Peterson, John, Shackleton, and Michael (2006), Santiso (2001), Farnz (2013) consider that Good Governance can be defined as an activity in decision making processes with managing public affairs between government and stakeholders. The second concept, interpreting good governance is a governance that follows public demand (Widodo, 2001). Finally, the third concept of good governance according to Bovaird and Löffler (2003) is an activity to managing public affairs which have been established and approved by all stakeholders. Based on all concepts above, the author develops the definition of good governance to be an important decision made by the government with managing public affairs and accepted by all stakeholders.

Good governance is needed to make a government institution's performance better than before. In the practice of establishing good governance, it is necessary to identify the principles that must be applied by a government institution to realize the good governance. Previous studies have been carried out in measuring good governance on satisfaction. For example, research conducted by Rejeb and Firoui (2012) on the contribution of good governance practices to the satisfaction of stakeholders from companies registered in Tunisia. This study resulted in a positive and significant relationship between the application of the three principles of good governance (responsibility, transparency, and accountability), the existence of prerequisites, and stakeholder satisfaction in companies registered in Tunisia. The assessment of all the above definitions makes measurement on good governance variables possible by modifying the dimensions of good governance as governance's principle: transparent, accountable, quality, negotiation, responsiveness clean and participation (Peterson, John; Shackleton and Michael, 2006; Bovaird and Löffler, 2003; Widodo, 2001; Franz, 2013) which is considered suitable to be applied to the research conducted. Determination of several principles - the principles of the experts come from the United Nation Development Program (UNDP). UNDP is a United Nations global development network which advocates change and connects countries with knowledge, experience, and resources to help build a better life. UNDP 
through LAN quoted by Tangkilisan (2005: 115) explains some understanding of the principles used in this study. The first principle is transparent, that is a principle that is built based on freedom of information flow that can be directly accepted by those who need it. Information must be understandable and can be monitored. Decision makers in government, as private and public (civil society) are responsible to the public and stakeholder institutions. The second principle is accountable, this principle depends on the organization and the nature of the decisions made, whether the decision is for the internal or external benefit of the organization. The third principle is responsiveness. It is the principle that makes institutions and institutional processes obliged to serve each stakeholder. The fourth principle is participation. It is the principle that involves every citizen in the formulation of decisions, both directly and through the intermediation of legitimacy institutions that represent their interests. The fifth principle is negotiation, namely the principle of building two-way communication designed to reach agreement when both parties have the same or different interests (Fisher \& Ury, 1991). The sixth principle is quality. Quality is overall nature of a product or service that influences its ability to satisfy expressed or implied needs (Kotler, 2005). The final principle is Clean which is the principle that requires government activities to be clean (Widodo, 2001).

Satisfaction is a feeling that is felt by all consumers. Studies of understanding satisfaction have existed long ago. Satisfaction means the difference between expectation and performance (Kotler, 2000). Also, satisfaction is a recognized value and created from the identification of the product or service with the offered price (Athanassopolos, 2000). While Bitner \& Zeithaml (2002) say satisfaction can be defined as an achievement of customer need and expectation through product or service. Satisfaction can be defined as a difficult process begin customer's expectations \& end with communication through experience (Zeithaml, 2000). In practice, satisfaction is an activity to compare between service quality and expectation that influences customer attitude (Diab, Mohammed, Mansour, \& Saad, 2016). Based on the above study it can be concluded that the similarities and differences of all definitions above are divided into two concepts. The first concept according to Kotler (2000), Zeithamal (2000), Bitner \& Zeithaml (2002) and Diab, Mohammed, Mansour, \& Saad (2016) is that satisfaction is created from comparing customer expectation and performance / quality through experience. Then the second concept says satisfaction created from the identification of the product or service with the offered price (Athanassopolos, 2000). Based on the concept of variables above, researcher will develop a variable satisfaction definition as an experience that is perceived by consumers as an assessment of their expectations of the quality of products / services at the price offered.

Measuring the level of customer satisfaction can reflect the quality of the company. The greater the sense of satisfaction that consumers eat will be directly proportional to the increasing quality / performance of the company. Consumers are not only in the company environment, but consumers are also present within the company. Internal consumers are employees of the company itself who get services from Susana's internal suppliers (2012: 36). In a study conducted by Jumadi (2014) on the influence of internal marketing and internal service quality on internal customer satisfaction and its impact on external customer satisfaction in the tourism industry in Yogyakarta Special Region resulted in internal customer satisfaction more influenced by the quality of internal services (companies). For this reason, it is necessary to measure the level of internal customer satisfaction based on the quality of service of the company. After reviewing all the above definitions, variable satisfaction is very possible to measure by modifying the dimensions obtained from the definition of satisfaction according to Kotler (2000), Athanassopolos (2000) and Zeithaml (2000), namely expectation, quality / performance, offered price and experience. In the context of customer satisfaction, generally expectations are estimations or beliefs about what customers will receive (Zeithmal, 
et al., 1993). Performance is a quality related to the main characteristics of a product (Garvin, 1987). Furthermore, regarding offered prices in this case is the pricing based on value, according to Kotler (2000) the price offered must be in accordance with the quality provided. The last is experience. Experience, in this case is the experience passed through by consumers. According to Meyer and Schwager (2007) experience is the response of consumers internally and subjectively because of direct and indirect interactions with the company.

This research makes lecturers and government as objects of research about perceived value and good governance on satisfaction of lecturers in state universities have not been widely carried out in Indonesia. Coupled with the lack of lecturers in Indonesia, the attention to fulfillment of lecturers' satisfaction must be maintained so that later university lecturers will be loyal to the government. For this reason, this research aims to find out the relationship between the variables mentioned above.

\section{RESEARCH METHODS}

Descriptive method with quantitative approach is the method chosen in this study. This research method is carried out by processing research results and then analyzed to draw conclusions. Based on the method described earlier, the authors conclude that this study emphasizes its analysis on numeric data (numbers). The author hopes the use of this research method tells of a significant relationship between the variables under study, so that later will produce conclusions that will describe the object under study. The focus of this research is only to measure perceived value and good governance on satisfaction lecturers at state universities. The scale used is Likert Scale, which is a scale of 1 to 5 to show the meaning of strongly agreeing to strongly disagreeing $(5=$ strongly agree, $4=$ agree, $3=$ doubt, $2=$ disagree, $1=$ strongly disagree.)

The populations in this study are all lecturers who teach at State Universities in Bandung. For sampling techniques, it uses non-probability sampling method type purposive sampling. Purposing sampling is a sample determination technique with certain considerations (Sugiyono, 2012: 96). The criteria for respondents that the author chooses as the subject of the study are respondents who taught as lecturers at state universities in the city of Bandung. Hair et al (1998: 637) suggested that the minimum sample size is as many as 5-10 observations for each estimation parameter. In this study, the number of research indicators was 45 so the minimum number of samples was $5 \times 46$ that is 230 respondents.

Structural Equation Modeling (SEM) is a method of analysis carried out in this study using Lisrel software. The purpose of using SEM analysis method is as an efficient and appropriate way to describe the structure of latent variables that underlie a set of observed variables. Goodness of Fit (variable variation) between models hypothesized with sample data can be done by SEM. SEM can also test the compatibility between observational data and the structure of the model made.

\section{RESULTS AND DISCUSSION}

Validity tests show the score of indicators perceived value variable, good governance variable and satisfaction $>0.5$, it means variable significant at $1 \%$ level $(\alpha=0.01): 0.2226,(\alpha=$ $0.05)$ : 0.1584 . Reliability tests show the extent to which a measuring device can provide 
relatively the same results when a repeat measurement is performed on the same subject. The reliability test in this study is conducted using SPSS.

Table 1. Variable Reliability Test

\begin{tabular}{ccc}
\hline Variabel & $\begin{array}{c}\text { Cronbach's } \\
\text { Alpha }\end{array}$ & N of Item \\
\hline Perceived Value (X1) & 0,946 & 12 \\
Good Governance (X2) & 0,987 & 25 \\
Satisfaction (Y) & 0,964 & 12 \\
\hline
\end{tabular}

The Cronbach's Alpha coefficient value of the three variables above is worth more than 0.8 , so the results of the questionnaire data have a good level of reliability, or in other words the results of the questionnaire data can be trusted.

Structural model is the relationship between latent variables (variables that cannot be measured directly and require several indicators to measure them) independent and dependent (Bollen, 1989). The results of the structural test model can be seen from the diagram below.

\section{Figure 1. Structural Model}

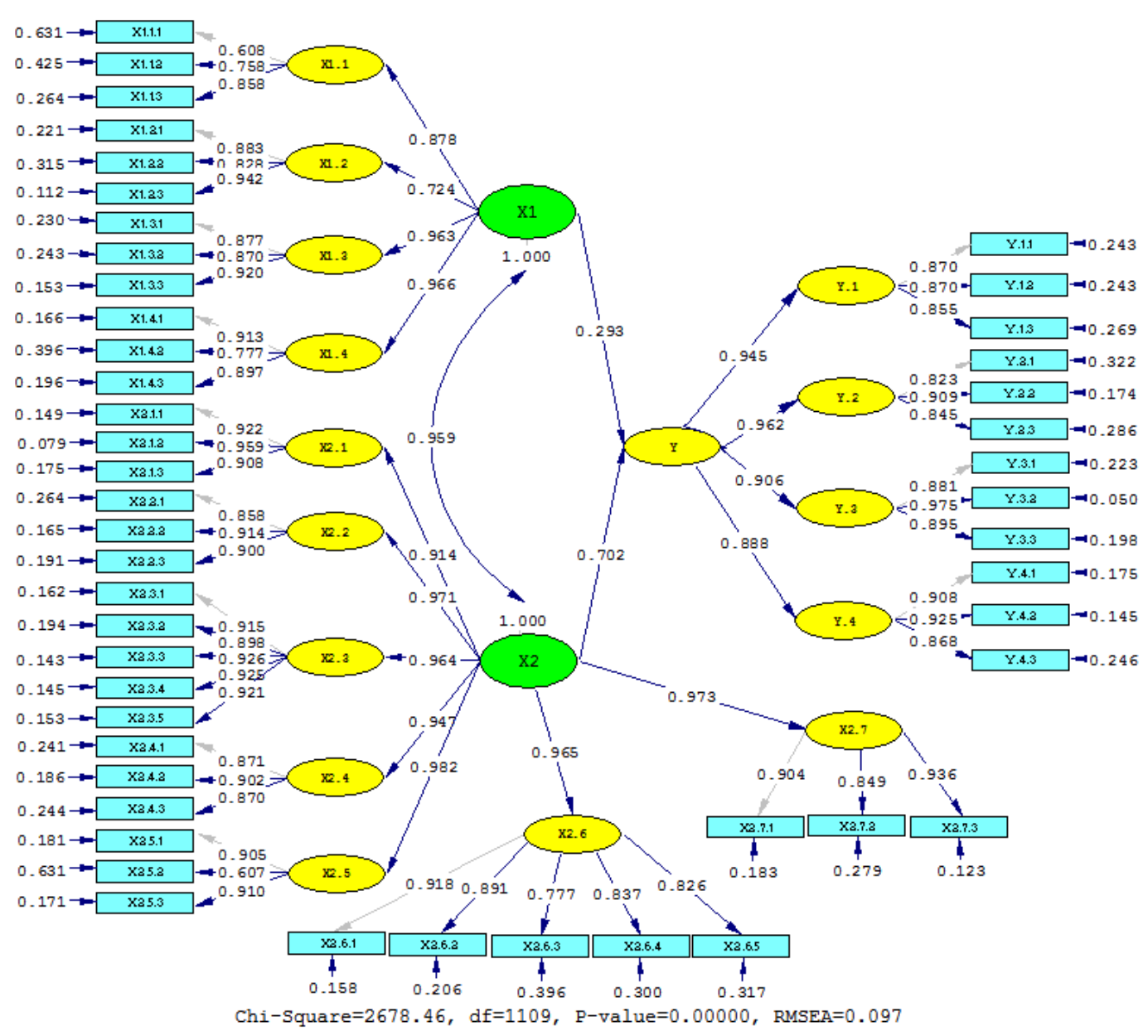


Based on the output of the calculation of LISREL 8.70, the standard factor load values are obtained and used to calculate the construct reliability coefficient values summarized in the following table:

Table 2. Standard Factor Loads and Construction Reliability

\begin{tabular}{|c|c|c|c|c|c|c|c|}
\hline $\begin{array}{c}\text { Latent } \\
\text { Variable }\end{array}$ & Dimension & $\begin{array}{l}\text { Observed } \\
\text { Variable }\end{array}$ & $\begin{array}{c}\text { Standardized } \\
\text { Loading } \\
\text { Factors }\end{array}$ & $\begin{array}{c}\text { Sum of } \\
\text { Standardized } \\
\text { Loading } \\
\text { Factors }\end{array}$ & $\begin{array}{c}\text { Measurement } \\
\text { Errors }\end{array}$ & $\begin{array}{c}\text { Sum of } \\
\text { Measurement } \\
\text { Errors }\end{array}$ & $\begin{array}{l}\text { Construct } \\
\text { Reliability }\end{array}$ \\
\hline \multirow{12}{*}{$\begin{array}{c}\text { Perceived } \\
\text { Value (X1) }\end{array}$} & \multirow[t]{3}{*}{$\mathrm{X} 1.1$} & X1.1.1 & 0,608 & \multirow[t]{3}{*}{2,224} & 0,630 & \multirow[t]{3}{*}{1,320} & \multirow[t]{3}{*}{0,789} \\
\hline & & $\mathrm{X} 1.1 .2$ & 0,758 & & 0,425 & & \\
\hline & & $\mathrm{X} 1.1 .3$ & 0,858 & & 0,264 & & \\
\hline & \multirow[t]{3}{*}{$\mathrm{X} 1.2$} & $\mathrm{X} 1.2 .1$ & 0,883 & \multirow[t]{3}{*}{2,653} & 0,220 & \multirow[t]{3}{*}{0,647} & \multirow[t]{3}{*}{0,916} \\
\hline & & $\mathrm{X} 1.2 .2$ & 0,828 & & 0,314 & & \\
\hline & & $\mathrm{X} 1.2 .3$ & 0,942 & & 0,113 & & \\
\hline & \multirow[t]{3}{*}{$\mathrm{X} 1.3$} & $\mathrm{X} 1.3 .1$ & 0,877 & \multirow[t]{3}{*}{2,667} & 0,231 & \multirow[t]{3}{*}{0,628} & \multirow[t]{3}{*}{0,919} \\
\hline & & $\mathrm{X} 1.3 .2$ & 0,870 & & 0,243 & & \\
\hline & & $\mathrm{X} 1.3 .3$ & 0,920 & & 0,154 & & \\
\hline & \multirow[t]{3}{*}{$\mathrm{X} 1.4$} & $\mathrm{X} 1.4 .1$ & 0,913 & \multirow[t]{3}{*}{2,587} & 0,166 & \multirow[t]{3}{*}{0,758} & \multirow[t]{3}{*}{0,898} \\
\hline & & $\mathrm{X} 1.4 .2$ & 0,777 & & 0,396 & & \\
\hline & & X1.4.3 & 0,897 & & 0,195 & & \\
\hline \multirow{18}{*}{$\begin{array}{c}\text { Good } \\
\text { Governance } \\
\text { (X2) }\end{array}$} & \multirow[t]{3}{*}{$\mathrm{X} 2.1$} & $\mathrm{X} 2.1 .1$ & 0,922 & \multirow[t]{3}{*}{2,789} & 0,150 & \multirow[t]{3}{*}{0,406} & \multirow[t]{3}{*}{0,950} \\
\hline & & $\mathrm{X} 2.1 .2$ & 0,959 & & 0,080 & & \\
\hline & & $\mathrm{X} 2.1 .3$ & 0,908 & & 0,176 & & \\
\hline & \multirow[t]{3}{*}{$\mathrm{X} 2.2$} & $\mathrm{X} 2.2 .1$ & 0,858 & \multirow[t]{3}{*}{2,672} & 0,264 & \multirow[t]{3}{*}{0,618} & \multirow[t]{3}{*}{0,920} \\
\hline & & $\mathrm{X} 2.2 .2$ & 0,914 & & 0,165 & & \\
\hline & & $\mathrm{X} 2.2 .3$ & 0,900 & & 0,190 & & \\
\hline & \multirow[t]{5}{*}{$\mathrm{X} 2.3$} & $\mathrm{X} 2.3 .1$ & 0,915 & \multirow[t]{5}{*}{4,585} & 0,163 & \multirow[t]{5}{*}{0,795} & \multirow[t]{5}{*}{0,964} \\
\hline & & $\mathrm{X} 2.3 .2$ & 0,898 & & 0,194 & & \\
\hline & & $\mathrm{X} 2.3 .3$ & 0,926 & & 0,143 & & \\
\hline & & $\mathrm{X} 2.3 .4$ & 0,925 & & 0,144 & & \\
\hline & & $\mathrm{X} 2.3 .5$ & 0,921 & & 0,152 & & \\
\hline & $\mathrm{X} 2.4$ & $\mathrm{X} 2.4 .1$ & 0,871 & 2,643 & 0,241 & 0,671 & 0,912 \\
\hline & & $\mathrm{X} 2.4 .2$ & 0,902 & & 0,186 & & \\
\hline & & $\mathrm{X} 2.4 .3$ & 0,870 & & 0,243 & & \\
\hline & $\mathrm{X} 2.5$ & $\mathrm{X} 2.5 .1$ & 0,905 & 2,422 & 0,181 & 0,984 & 0,856 \\
\hline & & $\mathrm{X} 2.5 .2$ & 0,607 & & 0,632 & & \\
\hline & & $\mathrm{X} 2.5 .3$ & 0,910 & & 0,172 & & \\
\hline & $\mathrm{X} 2.6$ & X2.6.1 & 0,918 & 4,249 & 0,157 & 1,377 & 0,929 \\
\hline
\end{tabular}




\begin{tabular}{|c|c|c|c|c|c|c|c|}
\hline & & X2.6.2 & 0,891 & & 0,206 & & \\
\hline & & X2.6.3 & 0,777 & & 0,396 & & \\
\hline & & X2.6.4 & 0,837 & & 0,299 & & \\
\hline & & X2.6.5 & 0,826 & & 0,318 & & \\
\hline & $\mathrm{X} 2.7$ & $\mathrm{X} 2.7 .1$ & 0,904 & 2,689 & 0,183 & 0,586 & 0,925 \\
\hline & & $\mathrm{X} 2.7 .2$ & 0,849 & & 0,279 & & \\
\hline & & $\mathrm{X} 2.7 .3$ & 0,936 & & 0,124 & & \\
\hline Satisfaction & Y.1 & Y.1.1 & 0,870 & 2,595 & 0,243 & 0,755 & 0,899 \\
\hline & & Y.1.2 & 0,870 & & 0,243 & & \\
\hline & & Y.1.3 & 0,855 & & 0,269 & & \\
\hline & Y.2 & Y.2.1 & 0,823 & 2,577 & 0,323 & 0,782 & 0,895 \\
\hline & & Y.2.2 & 0,909 & & 0,174 & & \\
\hline & & Y.2.3 & 0,845 & & 0,286 & & \\
\hline & Y.3 & Y.3.1 & 0,881 & 2,751 & 0,224 & 0,472 & 0,941 \\
\hline & & Y.3.2 & 0,975 & & 0,049 & & \\
\hline & & Y.3.3 & 0,895 & & 0,199 & & \\
\hline & Y.4 & Y.4.1 & 0,908 & 2,701 & 0,176 & 0,566 & 0,928 \\
\hline & & Y.4.2 & 0,925 & & 0,144 & & \\
\hline & & Y.4.3 & 0,868 & & 0,247 & & \\
\hline
\end{tabular}

Based on the table above shows that all latent variables have construct reliability coefficient values that are greater than or equal to the critical value (CR 60.6 ) and in the standardized loading factor value column, all observed variables have a greater standard factor load value than 0.5 , so that the observed variables can be used for further testing (can be used in the model).

Analyzing the relationship between constructs or variables that become hypotheses can done by looking at the $\mathrm{t}$-count value compared to the 1.96 value of each relationship between latent variables.

Table 4. Inter-construct relations

\begin{tabular}{|c|c|r|r|c|}
\hline Structural Equation & Impact & T value & Estimation & $\mathrm{R}^{2}$ \\
\hline$\eta=\gamma_{1} \xi_{1}+\zeta_{2}$ & $\xi_{2}$ on $\eta$ & 1.811 & 0.293 & \multirow{2}{*}{0.973} \\
\cline { 2 - 4 } & $\xi_{1}$ on $\eta$ & 3.210 & 0.702 & \\
\hline
\end{tabular}

From the results of the analysis of the relationships between constructs contained in the table above, it shows the results that: $\mathrm{X} 1$ variable does not significantly affect $\mathrm{Y}$ because the value of $t$-count $<1.96$ or $1.811<1.96$, where the magnitude of the influence is 0.293 , meaning that if $\mathrm{X} 1$ rises then $\mathrm{Y}$ also rises but not significantly. $\mathrm{X} 2$ variable significantly affects $\mathrm{Y}$ because the value of t-count> 1.96 or 3.210>1.96, where the magnitude of the influence is 0.702 , meaning that if $\mathrm{X} 2$ rises then $\mathrm{Y}$ also increases significantly. The R-square obtained is 
0.973 or $97.3 \%$, this shows that $\mathrm{X} 1$ and $\mathrm{X} 2$ together can explain $\mathrm{Y}$ by $97.3 \%$, while $2.7 \%$ is explained by other factors not examined in the model.

\section{CONCLUSION}

Based on the results of research that has been carried out, overall structural model test results are said to be good fit, it means this model can be used to find the impact of perceived value and implementation of good governance to satisfaction. Variable perceived value affect, but not significantly to lecturer's satisfaction. While good governance has a significant effect on lecturer's satisfaction.

There is a limitation in this study, namely the research is only conducted in Bandung. Better results regarding lecturer satisfaction will be obtained if this research is conducted not only within the scope of the city, for example in the scope of the province, island, and country. Furthermore, it is expected that future research can exceed this limit, so that the results of their research can be more comprehensive about the impact of perceived value and good governance on lecturer satisfaction.

\section{REFERENCES}

(UNDP), U. N. (1997). Governance and Sustainable Human Development. Norwalk, CA, USA: UNDP Governance Police Paper.

Athanassopolos, A. D. (2000). Customer Satisfaction Cues to Support Market Segmentation and Explain Switching Behaviour. Journal of Business Research, 191-207.

Bovaird, T., \& Löffler, E. ( 2003). Evaluating the Quality of Public Governance: Indicators, Models and Methodologies . International Review of Administrative Sciences , 313 328.

Day, G. S. (1999). Market Driven Strategy: Processes for Creating Value. New York: The Free Press.

Diab, D., Mohamed, H., Saad, O., \& Mansour, I. (2016). Investigation of Dineserv dimensions on customer satisfaction \& loyalty: Evidences from the restaurant industry in Sudan. NCM Conferences.

Fisher, R., Ury, W., \& Paatton, B. (1991). Getting to Yes: Negotiating Agreement Without Giving in. New York: Penguin Books.

Franz, T. (2013). Einführung in die Verwaltungswissenschaft. Wiesbaden: Springer VS.

Gale, B. T. (1994). Managing Customer Value: Creating Quality and Service That Customer Can See. New York: Simon and Schuster.

Garvin, D. A. (1987). Managing Quality. New York: The Free Press. 
Jayakodi, D. H., Samarasinghe, G. D., \& Kuruppu, G. N. (2016). The Effect of Customer Perceived Value on Customer Satisfaction \& Loyalty: A Case of Sri Lankan Pay-TV Industry. National Council of Teachers of Mathematics.

Kotler, P. (2003). Marketing Insights from A to Z: 80 Concepts Every Manager Needs to Know. New Jersey: John Wiley \& Sons.

Kotler, P., \& Armstrong, G. (2005). Principles of Marketing 11 th Edition. Upper Saddle River: Prentice-Hall.

Meyer, \& Schwager. (2007). Understanding Customer Experience. USA Harvard Business Review, 1-12.

Parasuraman, A., \& Grewal, D. (2000). The Impact of Technology on The Quality Value Loyalty Chain: a Research Agenda. Journal of The Academy of Marketing Science, 16874.

Peterson, J., \& Shackleton, M. (2006). The Institutions of the European Union 2nd Edition. New York: Oxford University Press.

Rejeb, W. B., \& Friouni, M. (2012). The Impact of Good Corporate Governance Practice on Stakeholder's Satisfaction in Tunisian Listed Companies. International Journal of Business and Management Studies.

Santiso, C. (2001). Good governance and aid effectiveness: the World Bank and Conditionality. Georgetown Public Policy Review, 1-22.

Schmitt, B. H. (1999). Experiential Marketing . Journal of Marketing Management, 53-67.

Smith, J. B., \& Colgate, M. (2007). Customer Value Creation: a Practical Framework. Journal of Marketing Theory and Practice, 7-23.

Snoj, B., Korda, P. A., \& Mumel, D. (2004). The relationships Among Perceived Quality, Perceived Risk and Perceived Product Value. Journal of Product and Brand Management, 156-167.

Susana, J. (2012). Developing the Internal Service Quality in Organisation Y. Business Management Bachelor's Thesis Laurea . University of Applied Sciences.

Sweenay, J. C., \& Soutar, G. (2001). Consumer Perceived Value: The Development of Multiple Item Scale. Journal of Retailing, 203-220.

Xin, W., Changzeng, H., \& Bing, Z. (2016). Relationship Between Customer Perceived Value and Loyalty of Mobile banking. International Conference on Education, Management, Computer and Society.

Zeithamal, V. A. (1988). Consumer Perception of Price, Quality, anda Value: a Means-End Model and Synthesis of Evidience. Journal of Marketing2-22. 
Email : editorijhess@gmail.com

Zeithaml, Berry, \& Parasuraman. (1993). The Nature Determinants of Customer Expectations of Service. Journal of The Academy of Marketing Science.

Zeithaml, V. A., \& Bitner, M. (2002). Service Marketing (2nd Edition). New York: McGrawHill.

Zethamal, V., Bitner, \& Gremler. (2000). Service Marketing. Singapore: Mc.Graww-Hill Companies Inc. 